\title{
Bridging theory to practice with classroom rounds
}

\section{Connie L. Bowman ${ }^{1}$ and Janet M. Herrelko ${ }^{2}$}

\begin{abstract}
Pre-service candidates' perceptions of how to teach were challenged after going through the process of Classroom Rounds, the process that was used in this study. Classroom Rounds consisted of a pre-conference meeting with an inservice teacher, followed by a classroom observation of that teacher, and finally a discussion focusing on proven evidence-based practices. The pre-service candidates had the opportunity to share their observational data and beliefs about teaching with that experienced classroom teacher, and then they learned the practical context of research-based pedagogical practices in a classroom setting. Rounds, in combination with clinical experience, extended the pre-service candidates' awareness of research-based practices, conveyed the importance of these practices, and showed specific techniques for implementing these practices in their classrooms. The positive impact these observed practices had on the preservice candidates' classroom procedures were later revealed in surveys that they completed after their student teaching.
\end{abstract}

Keywords: Pre-service candidates, folk pedagogy, pedagogical practices

\section{Bridging Theory to Practice with Classroom Rounds}

Many pre-service candidates enter their senior year of college with the belief that they not only have mastered educational theory and learned all pedagogical techniques, but also have ascertained sufficient content knowledge to teach in a classroom setting. Their desire to be teaching in a real classroom rather than sitting in another college class is palpable. The dilemma for teacher educators is how to change the pre-service candidates' overreliance on intuitive/tacit pedagogical knowledge, or on teaching as they themselves were taught, and convert them to implementing the concepts and practices learned in university courses (Torff, 1999). This dilemma led to the research question for this study: Can Rounds visits in classrooms influence pre-service candidates' perception of teaching by lessening their reliance on intuition and increasing their use of research-based practice?

\section{Purpose of the Study}

The university faculty responsible for teaching content methods created this study to learn ways to dislodge and reorganize the pre-service teachers' intuitive approach to teaching by giving the pre-service candidates glimpses into the real work of teaching through the use of Classroom Rounds. The term Rounds in this study represents a method similar to the medical model in which residents observe practicing doctors examining patients, pose questions, and then receive responses based on data presented by the doctors. The educational Rounds model uses three stages: pre-service candidates first have a conference with a classroom teacher, then they

\footnotetext{
1 Associate Professor, University of Dayton, 300 College Park, Dayton, Ohio 45469-2699, cbowman1@ udayton.edu

2 Associate Professor, University of Dayton, 300 College Park, Dayton, Ohio 45469-2699, jherrelko1@udayton.edu
} 
observe and collect data on an actual teaching episode, and then they have a post-conference to engage in professional reflection (Del Prete, 2006). Grounded theory emerging from sensitizing concepts was the theoretical framework for this study (Bowen, 2006). By using this inductive methodology, the researchers hope to find themes regarding candidates' reliance on intuitive/tacit knowledge of teaching and increase their use of research-based pedagogical strategies. Data provided from this study should benefit both educational researchers and methods faculty in schools of education.

The literature researched for this study examined what has been and is currently being done with Classroom Rounds in teacher education. The content methods faculty conducting this research questioned how to move the pre-service candidates beyond their simple reliance on observed teaching practices that they personally experienced as students to a greater reliance on those practices that were research-based. The literature has clearly noted the impact of classroom Rounds on pre-service candidates. This study sought to extend the findings to examine the jump from intuitive teaching to research-based practices.

\section{Rounds models}

In the medical profession, grand rounds are an integral feature of physician training. During rounds, medical residents learn clinical reasoning skills and develop knowledge of specific pathologies through observations of patient cases and discussions with experienced physicians pertaining to those patient cases. The medical models have been structured in a variety of ways, but they were traditionally conducted bedside and included clinical examinations of patients. More currently, rounds are likely to include presentation of data on particularly intriguing cases, with no patient interaction (Thompson \& Crooner, 2001).

Rounds in Teacher Education Settings. The term Rounds has been drafted into the educational professional development lexicon from medical education. There are various strategies incorporated into Classroom Rounds, but each strategy strives to develop professional knowledge through analysis of data from specific clinical cases. Previous work by Virtue (2009) found the Rounds strategy had benefits in challenging assumptions about English language learners and suggested incorporating Rounds into teacher education programs. Thompson and Cooner (2001) documented Rounds working with pre-kindergarten through $4^{\text {th }}$ grade professional development schools. They found that this strategy improved educational practice by providing "first-hand experience in observing, questioning and reflecting on the 'best practice' strategies of master teachers in a collaborative and supportive environment" (p. 87). Thompson and Cooner also noted that mentor teachers found questions from pre-service candidates equally helpful in reflecting on their personal instructional practice.

During Rounds sessions at Project Zero, classroom teachers closely examined student work and discussed issues about project-based learning (Blagg, 2009). In another variation of Rounds, superintendents observed classrooms and engaged in collegial evidence-based conversations on pre-identified problems (Rallis, Tedder, Lachman, \& Elmore, 2006). Based on this work (Rallis et al., 2006), groups of Scottish teachers and administrators then commenced "learning rounds," classroom observations followed by evidence-based discussions, in order to learn about and from school practices (Graham, 2008).

The standards set up by the National Council of Accreditation of Teacher Education Professional Development School (PDS) called for learning opportunities for all stakeholders. It was recognized that Rounds had the potential to provide collegial learning opportunities which 
were often lacking in schools (Lortie, 1975; Sarason, 1996), created a channel for communication about educational practice between school and university faculty, and provided all participants with occasions for situated learning in context of practice (Lave \& Wenger, 1991; Thompson \& Cooner, 2001, Ladson-Billings, 2008).

The pre-service candidates' educational program in this study. During their first year, all pre-service candidates at this university take part in their first field placement. They are assigned focused field observations related to teacher standards, as well as reflective papers based on observations of teaching and learning, and they investigate the concept of teaching and student learning through other specific assignments. Sophomore year stresses the connections that their class readings and assignments have to their second field placement, and this year also includes tutoring, as well as a case study conducted at an urban partner school. The junior year field experience engages pre-service candidates in the process of teaching itself. They prepare lesson plans, tutor small groups, co-teach, and then solo teach one class session. During the fall of their senior year, pre-service candidates enroll in content methods courses. These courses are content specific, with the emphasis on research-based strategies and methods, and pre-service candidates incorporate these elements into units of study. Figure 1 summarizes and details the flow of the fieldwork required at this university. Additionally, Figure 1 notes when data were collected during this study.

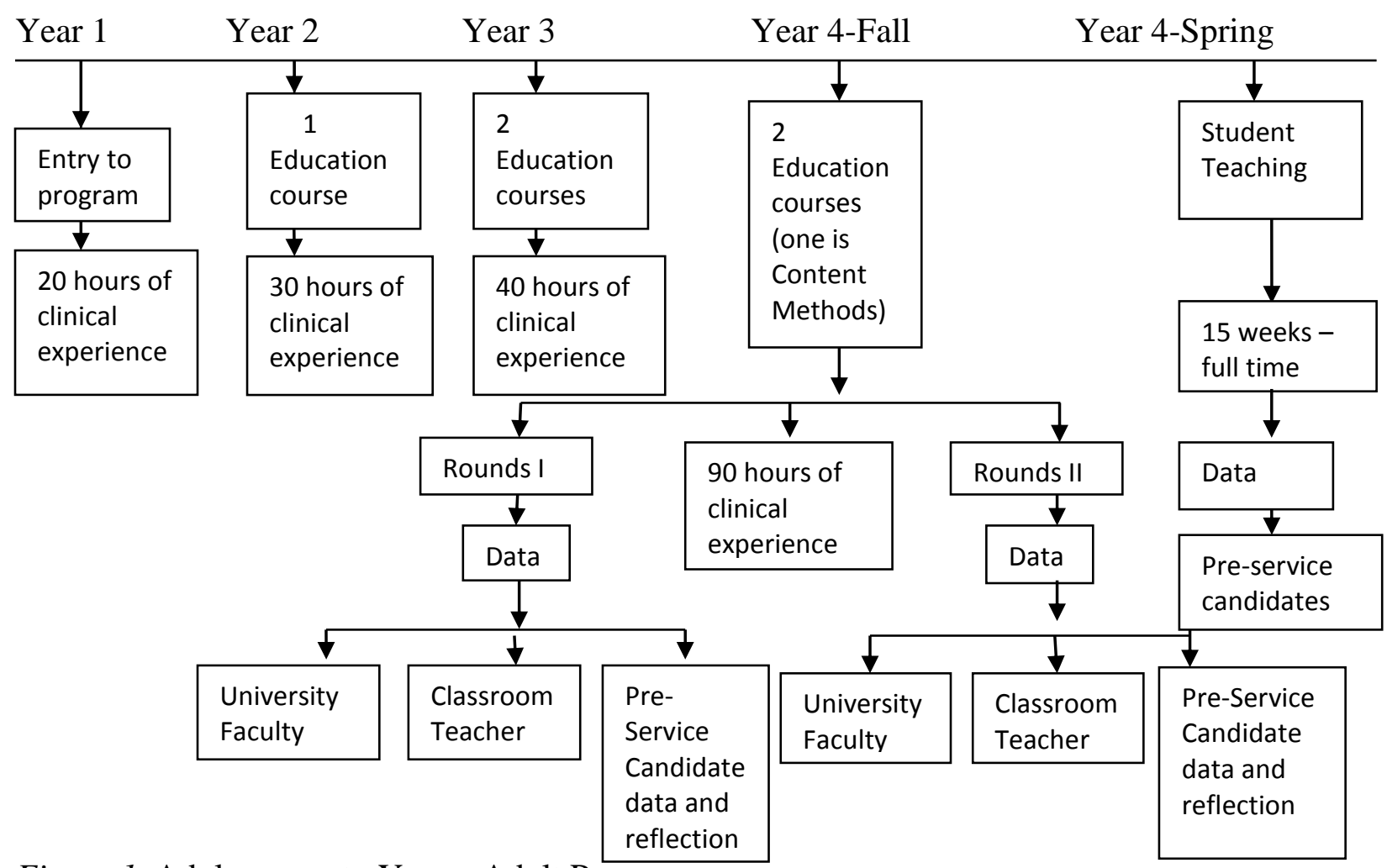

Figure 1. Adolescence to Young Adult Program.

The progression from first year to senior year moves from focused observations to the development of a teaching repertoire, and it involves many steps: one-on-one tutoring, small group tutoring, whole group teaching, simulations, and micro-teaching. All experiences lead to student teaching. The fall semester of the senior year engages the pre-service teachers in half-day 
teaching for six weeks. The pre-service teachers co-teach lessons, move on to solo teaching, and then progress to student teaching for fifteen weeks the following semester. All the time spent in preparation fieldwork finally comes to fruition for the pre-service teacher with the connection of theory to practice taking center stage in the classroom during student teaching.

For this study, Rounds I occurred at an urban partner school during the senior fall semester and early in the methods course. It was followed by a 90 -hour field placement that lasted for six weeks. Pre-service candidates then returned to their methods courses and participated in Rounds II, scheduled at the same urban school.

\section{Definitions of classroom observation methods}

The types of classroom observation methods taught to the pre-service candidates were provided in a seminar prior to Rounds. During this seminar, students practiced each of the following methods to ensure they could use each one effectively:

1. The selective verbatim technique (Acheson \& Gall, 1987) scripted one aspect of classroom discourse, tracking either what the teacher was saying or how the students responded.

2. Verbal flow (Walsh, 2002) kept track of whom was participating in classroom discussions. No scripting was done; instead, a symbolic classroom seating chart was used, with arrows showing the flow of questions/responses or the flow of discussion among the teacher and students.

3. Engagement time (Gibson \& Dembo, 1984) used letters $($ on $=0$; off task $=$ ot $)$ to represent student actions in class during a specific time frame.

4. Question typology (McNamara, 1981) recorded all questions posed by the teacher during the designated time and then analyzed the questions according to categories.

5. Class traffic (Everston \& Smithey, 2000) followed the movements of the teacher on a seating chart, noting where the teacher stopped to work with students.

6. Interactive analysis method (Amidon \& Hough, 1967) tracked the teacher's classroom behaviors with students within given timeframes by using coded categories that the teacher and observer had determined beforehand.

7. Global scan method (Wainwright, Flick, \& Morrell, 2003) required the observer to write anecdotal notes as events happened within the classroom.

\section{Method}

The most frequently referenced pre-service Rounds model was developed by Del Prete (1997, 2006) at Clark University in Massachusetts. The model included a pre-observation discussion of the planned lesson, an observation, and a post-observation discussion among preservice candidates, teachers, and college faculty. For this study, Del Prete's model was used, along with ethnographic methods for data collection. 


\section{The Research Question}

This ethnographic study investigated the impact of Rounds before and after a clinical experience, and post-student teaching, to learn if Rounds could diminish the pre-service candidates' reliance on intuitive/tacit knowledge of teaching and increase their use of researchbased practices. A qualitative design was chosen as the methodology for this research because it provides the basis for a substantive theoretical question (Bogdan \& Biklen, 1992). The research question is: Can Rounds visits in classrooms influence pre-service candidates' perception of teaching by lessening their reliance on intuition and increase their use of research-based practice?

\section{Procedure}

The study began with visits to classroom teachers based on two content areas: English and mathematics. Procedures followed the Del Prete model (2006). After each Rounds visit to schools, the pre-service candidates answered a set of questions about their observations on the teaching and pedagogy that occurred during the visit. This was accomplished in person during the following content methods class. Then, at the end of their student teaching during a final seminar, the pre-service candidates completed a survey asking what pedagogical practices observed during Rounds were used during their student teaching. This main research question guided the document review and the interviews with key informants. The interviews elicited the perceptions of the key informants as they participated in the Rounds episodes. Key informants included classroom teachers who had taught during the Rounds episodes, pre-service candidates who had observed and collected data of the teaching event, and university faculty who had taught methods courses and who had taken notes on the pre-service candidates' activities.

From the document reviews and interviews, case studies were developed. Case studies were chosen because of their "usefulness in making human actions and interventions more effective and by its practical utility to decision makers, policy makers and others who have a stake in efforts to improve the world" (Patton, 1990, p. 12). Sensitizing concepts became evident from the case studies that produced themes. Qualitative research best captured the voices of the key informants.

\section{Participants}

This Rounds model implementation studied the Adolescence to Young Adult (AYA) English Language Arts and Mathematics pre-service teachers. The demographic data follows in Table 1.

Five high school teachers were observed: one mathematics teacher, observed three times; four English teachers, each observed one time. The teachers observed had five to ten years of experience in classroom teaching. These numbers represent the total number of senior preservice candidates enrolled in the methods courses for mathematics and English Language Arts. Our goal was to observe content-specific classes, and the expertise of the researchers was in the areas of English Language Arts and mathematics. This limitation kept the numbers of participating pre-service candidates low. The number of teachers observed in this study was based on the availability of the teachers and their schools' policies regarding visitors to the school buildings. 
Table 1

AYA Program Participants in the Study

\begin{tabular}{llllll}
\hline Program Year & \multicolumn{2}{c}{ Language Arts } & & Mathematics & $\begin{array}{l}\text { Total } \\
\text { Students for } \\
\text { the Program } \\
\text { Year }\end{array}$ \\
\hline & Female & Male & $\underline{\text { Female }}$ & Male & \\
\hline 1 & 10 & 2 & 4 & 3 & 19 \\
2 & 12 & 0 & 7 & 3 & 22 \\
3 & 7 & 3 & 5 & 0 & 15 \\
\hline Totals & 29 & 5 & 16 & 6 & 56 \\
\hline
\end{tabular}

Setting. The school used in this study is an urban charter high school associated with a large, urban school district and a Midwestern university. The mission of the school is to prepare inner-city students who are from the first generation in their families to attend college. One hundred percent of the graduates are accepted at either a two-year or four-year college. Enrollment is sustained year to year at a rate of $90-95 \%$. The ratio of students to teachers is $8: 1$. The composition of the student population is 83\% African American, 12\% Caucasian, 2\% Hispanic, $2 \%$ Asian, and 1\% other populations.

Preparation of pre-service candidates for the study. To prepare the pre-service candidates for active participation in the Rounds observations, seminars were conducted in which ethnographic data methods were introduced. These observation methods included: selective verbatim, verbal flow, time-on-task, question typography, class traffic, interaction analysis, and global scan.

The researchers, who were the content faculty, employed Del Prete's (2006) three-part process for Rounds: a pre-observation conference, a classroom observation, and a postobservation conference. During the pre-observation conference, the pre-service candidates and university faculty met with the classroom teacher to review the lesson plan, to ask questions about the content of the lesson, to get an explanation of the planning process, to identify lesson objectives, and to discuss the rationale behind the selected pedagogies that would be used in the classroom. The teacher requested that the pre-service candidates observe a specific aspect of his or her teaching to assist the teacher's professional growth. For example, one teacher requested that pre-service candidates record data of whether every student was engaged through the questioning process. After a 55-minute observation and data collection, a post-observation conference was conducted. The candidates had many questions for the teachers after the observation regarding classroom procedures, strategies, and how the teachers handled specific student behaviors and why.

In addition to these observational techniques, the content methods faculty created a set of questions completed by the pre-service candidates when they returned to their methods class the week following Rounds. The purpose of the questions was to provide a focus for the pre-service candidates' reflection on data from the observations. These questions included the following:

1. What did you learn about teaching from your observation of the classroom lesson at the urban charter high school?

2. What did you learn about students in a classroom?

3. What new pedagogical methods/practices did you observe? 
4. How are you planning to incorporate student-centered teaching into your classroom?

\section{Data Collections}

Data collections occurred at five points during the academic year. The first data point was the pre-service candidates' observation notes, the university faculty's notes, and the classroom teachers' comments from Rounds I. The second data point involved the pre-service candidates' written reflections in response to guided questions. During Rounds II after the five-week field experience, the third data point was the candidates' and faculty observation notes and the classroom teachers' comments. The fourth data point was the candidate reflections in response to the guided questions. The fifth data point was a questionnaire that was administered following completion of a 15-week student teaching experience at the AYA Capstone seminar (Herrelko \& Bowman, 2011) regarding the impact of the Rounds sessions on their student teaching experience and on their future teaching.

Data were collected from two sources: pre-service candidates and university faculty. Faculty notes and pre-service candidates' notes and reflections were used. During the observation, pre-service candidates collected data responding to the teacher's request and focused on the questions distributed during the methods class. These were collected for the researchers' data review of themes regarding what was noted by the pre-service candidates. Following the Rounds, pre-service candidates completed a reflection paper in their next methods class that was given to the researchers. Reflections written during methods classes were collected for data sorting. The faculty notes were records of what the pre-service candidates were doing, what they attended to during the observation, and what assistance they offered to the students in the classroom. Using the combination of the collected pre-service candidates' observation notes and reflections, and the faculty notes, there were a variety of data to be sorted for themes.

\section{Data Analysis}

Sensitizing concepts have been regarded by researchers as being useful for providing a focus to guide qualitative methods (Blumer, 1979; Denzin, 1989; Patton, 1990). In this study, our knowledge of content, of pedagogical methods, of strategies, and of the relevant research served as sensitizing concepts and influenced our data analysis. Analysis for themes was conducted using card-sorting techniques of the pre-service candidates' responses on the observation sheets and of their reflections. The analysis was conducted to identify categories and to note if differences existed between the responses made pre-observation and those made postobservation. Each of the five sets of data were analyzed and examined for common terms and themes.

\section{Findings}

After the researchers examined the data and reflections following Round I, they noted three categories emerged, presented here in descending order of the number of times mentioned: classroom management techniques, strategies used to present content, and fast assessment techniques.

Classroom management techniques. Pre-service candidates identified elements of classroom management that were covered in their university classes. Their data identified when 
students were on task or off task, defined by the pre-service candidates' interpretation of what on task required (i.e., correct responses to questions). They noted how the teacher controlled the classroom with specific practices, such as the techniques the teacher used in calling upon students when they had questions, needed help, or wanted to answer a question (e.g., hand raising, raising a card).

Strategies for content presentation. The pre-service candidates identified and recorded many of the instructional strategies used by the in-service teachers. These included the use of smart boards, advanced organizers, visual aids, video games, and collaborative learning strategies. The pre-service candidates recorded these strategies for their use and noted them in their reflections.

Fast assessment techniques. The formative assessment methods used by the in-service teachers were identified by the pre-service candidates as "easy assessment methods." These methods included having the students use thumbs up for understanding the presented information, thumbs down for not grasping the information, and thumbs turned sideways for not fully understanding the information. Another classroom teacher implemented colored cards, with three differing colors representing the same three levels of understanding as the thumbs-up method. The use of yes/no slips to indicate understanding was a third method listed. And a fourth method was noted several times by the pre-service candidates: the use of white boards to alert the teacher to student responses throughout a classroom.

Faculty recorded observations. The researchers reviewed the university faculty's data from the pre-observation meetings between the pre-service candidates and the classroom teachers. The faculty noted that the pre-service candidates asked few questions of the teacher following the teacher's explanation of what would be taught. This lack of questioning was noted by one faculty member and then contrasted with the pre-service candidates' interactions with the in-service teacher after the observation. The teacher had asked that the pre-service candidates observe to whom she was asking the most questions, where she focused her instruction, and if she worked with one group of students more than the rest of the class. This in-service teacher wanted a neutral party observing her classroom practice in order to improve her practice. Another teacher asked that the pre-service candidates observe what level of questioning the teacher used. In fact, each in-service teacher asked that different teaching practices be observed. The faculty noted what the pre-service candidates did during the class itself, such as taking notes and being involved with the students.

\section{Rounds I}

In the mathematics and English classrooms, each teacher had requested that the preservice candidates observe and collect data on the students' engagement based on the questions asked by the classroom teachers and students. Each of the pre-service candidates selected his or her own coding system and tracked as many students in the classroom as possible. The coding defined behaviors and interactions between classmates as well as between the classmates and the teacher. The pre-service candidates took notes on what was happening in the class during instruction, which produced the listing of classroom practices that they had been taught and that they had applied in their university classes. Their reflection papers summarized their data collections and observations into readable form. 
The concern about how to manage students in the classroom while presenting abstract concepts was a concern that the pre-service candidates noted in both the mathematics and English Language Arts methods classes and a concern that their reflection papers emphasized:

- It's not new, but having the day's schedule on the board (although never discussed) kept the students on track and informed.

- The teacher was moving quickly through the bell work on grammar errors and the group presentation forced students to pay attention.

There were several observations regarding teaching strategies that the classroom teacher used:

- I learned about having to pay attention to those both with questions and those 'without.'

- I saw an actual example of using scaffolding to help a student get the right answer instead of just telling them.

- Questioning strategies are vital to a student's ability to learn a concept w/o the teacher giving an answer.

No one made an observation about assessment techniques in the English class, but one pre-service teacher in the mathematics classroom noted this about assessment techniques:

- By giving prior knowledge quizzes and surveys that test what my students already knew about a topic being introduced, I will start my lessons where the majority are and I can differentiate the instruction.

- I also saw another example to adapt the use of exit slips when time is not as planned.

In the post conference discussion, the pre-service candidates asked many questions that concentrated on the "why" of strategy selection. All of the pre-service teachers wanted to know details about how the lesson was structured and planned. They asked for the purpose of the lesson beyond fulfilling state mandates. The teachers were very open and explained their rationale for selecting the pedagogical strategies and practices. One teacher noted that "In prior years, I delivered the content by lecture and my students failed to master the content. I wanted to use something different this time that was related to their world to test if this engagement would help them grasp the concept." The pre-service candidates were impressed that this experienced teacher would share her failure to help students learn and her attempts to improve her instruction.

Concerns about classroom management appeared in all the reflection papers written by the English pre-service candidates. Pre-service candidates were surprised at the simple techniques used by teachers. In the 8th-grade English Language Arts classroom Rounds, one observer wrote the following comment:

- The teacher stopped teaching and said "I'll wait." Then she paused for about 10 seconds and the students returned to their task.

Another set of Rounds conducted in a 10th-grade English class led to this statement:

- I was surprised at how focused the students were and the groups worked well together.

The researchers' review of the pre-service candidates' notes and reflections found that the majority reported what they saw, but that there were no references to any connections to their practice. The pre-service candidates stated that Rounds were an opportunity to see an authentic teaching episode in their field teaching and to see some different ways to present content.

\section{Rounds II}

Card sorting of the classroom notes and reflections produced after Rounds II turned up the same thematic categories as those in the pre-clinical experience, but these categories appeared in a different order of concern, from highest to lowest. This time the major concern was 
with teaching strategies, followed by classroom management, and then assessment techniques. The nature of the notes was more detailed, providing rationales and giving suggestions for what could be done in the future or when they used the technique. These descriptive details noted the pre-service candidates' new ability to analyze and synthesize the strategies they observed.

One example of such analysis and synthesis occurred during a pre-observation conference interview with the mathematics teacher following the candidates' 5-week clinical experience. The pre-service candidates were very wary about asking questions regarding mathematical terminology being used in a lesson-even though they did not understand it. The university faculty recognized the blank stares of the pre-service candidates and asked the teacher to explain what a "dot product" was and how it was calculated. After the classroom teacher's explanation, the pre-service candidates had many questions for the teacher; most of them focused on what to do when a teacher is required to teach new content with which the teacher is not unfamiliar. In response, the classroom teacher noted resources to use and cautioned the preservice candidates about terminology changing from one textbook to another. Then the teacher requested that the pre-service candidates engage with the students to assist them in their practice with the mathematical process of dot product calculations during Rounds II.

In the English post-observation conference session of Rounds II, the pre-service candidates shared data that noted one section of the class that had not been involved in the lesson or discussion. The teacher had asked the pre-service candidates during the pre-observation conference to monitor participation and active engagement of this section of her class. After preservice candidates shared their data, the teacher told them that their data were accurate and noted that this one section's lack of involvement was a daily occurrence. The teacher and pre-service candidates then discussed the data presented, came up with possible reasons for disengagement, brainstormed some solutions, and then settled on a possible response. The teacher took their suggestions and stated she would implement the change and report back to them with the results. The pre-service candidates were very surprised that the teacher took their suggestions, and they began to understand that they were viewed as colleagues by the teachers.

The reflection papers from Rounds II presented a broader view of each observed classroom. The pre-service candidates identified methods and strategies used by the teachers and discussed how these supported student learning. They added the rationale for using the selected methods and strategies in their responses. The responses were more in-depth, noting how they would use the strategy, or how they had used it during their clinical experience, and offering detailed reasons for doing so. The pre-service candidates during Rounds II asked more questions of the teachers concerning practice and theory than they had during the Rounds I session. They were now asking "Why" and "How" questions of the teachers. They were connecting theory to practice in reference to the observed teaching episodes:

- Why did you select that strategy?

- I do not understand how this fits with the content standards.

Teaching strategies noted by the pre-service candidates were the most frequent comment in Rounds II. Following are two examples of pre-service candidates' responses:

- The importance of questioning and examples especially to correct students' misconceptions. Relate math concepts to actual life to grab students' attention. The importance of being able to think on your feet, and when to ask the students WHY problems are solved in a certain way. 
- Student-centered classrooms are essential for learning. By focusing on students and taking on the role of facilitator in the room, allows them to lead discussions and pose questions.

Comments made by the pre-service candidates regarding classroom management included the following:

- Time management is an issue and seemed to know when to move on, when to help the student and when to just give information.

- Class traffic is something that I observed in classes. It is interesting because I never thought how important it is to move around the classroom not only for classroom management, but to make sure students know you are there to help.

Regarding assessment techniques, the mathematics and English pre-service candidates only noted one observation from each group:

- Pop quiz bell ringers can serve as a formative assessment and give students an idea of how much they need to study the material.

- The three check points for the research paper are excellent. This lets students know where they are, what is needed, and where they need to be prior to completing the projects.

In the post-observation conference discussion, the pre-service candidates were more at ease with the teachers. They shared data, identified difficult elements of the lesson, and discussed how teachers were building on students' prior knowledge to assist them with the new content knowledge being introduced. The pre-service candidates noted the scaffolding used by the teachers to help students construct meaning.

\section{Post Student Teaching}

At the end of the student teaching semester, pre-service candidates took part in a required final seminar. Data for the university was collected and the pre-service teachers completed state required surveys. It was during this seminar the researchers asked the AYA mathematics and English Language Arts pre-service candidates to respond in writing to the following two questions:

1) List any ideas/techniques that you observed during Rounds that you used during your student teaching.

2) Identify two methods/strategies that you observed during Rounds that you intend to use in your teaching practice.

The end of student teaching surveys demonstrated the long-term impact of Rounds on pre-service candidates. Four categories emerged from the responses: strategies, assessment, classroom management, and technology.

Strategies. The responses detailing various strategies that they observed during Rounds noted how they employed the strategies during student teaching and that these strategies helped to focus the work of students on specific content. When asked which areas will these pre-service candidates use in their practice, they identified the research-based teaching strategies as of prime importance for their own classrooms.

Assessment Techniques. Assessment techniques and technology were noted for use in their own classrooms. The importance of assessment dropped for these pre-service candidates from the semester prior to student teaching. 
Classroom Management. Pre-service candidates noted how the teachers were managing their classrooms and included the research as to why these techniques worked. They identified the use of multiple strategies for keeping the students on task, having posted classroom procedures and consequences as two means of management. In their reflections they identified links to research, such as the work of the Canters regarding classroom management.

Technology. The area of technology was noted as being important to their own classrooms. These pre-service candidates were very familiar with social media. How they use technology in the classroom to help students generate knowledge products will be the new arena in which to create teaching strategies.

The high-impact memories that the pre-service candidates held and used in their student teaching focused on teaching strategies and how to engage students in their content areas. During the observations and use in their student teaching, classroom management was the second most important concern. There was a switch between observed and used assessment techniques from student teaching to what they will use in their own practice. Assessment issues were of greater concern for implementation when these pre-service candidates are in their own classrooms. Technology use was not mentioned either in the observations, nor how they implemented it in their student teaching; however, several mentions were made about how to use technology in their own classrooms in the future. A notable element from their reflections was the comparison of one observed teacher with another in the same content area. While the two observation dates were weeks apart, the pre-service candidates were able to recall the actions of one in-service teacher and compare those to another in-service teacher. This observation identifies the need for the faculty to involve more in-service teachers in the program for the pre-service candidates to observe. At the conclusion of their student teaching, the candidates completed surveys providing information regarding the impact of Rounds on the practices used by them during student teaching and also regarding what they planned to do with information learned during the Rounds observations.

\section{Conclusion}

During Rounds I, pre-service candidates identified elements of classroom management, teaching strategies, and easily identified assessment techniques recently covered in their methods course. During the mathematics Rounds, the pre-service candidates were looking for correct answers to the mathematics. The English pre-service candidates were focused on how the content was presented to engage students. Their concerns about classroom management, teaching strategies, and assessment techniques were at a very novice level. The pre-service candidates were at the very basic levels of Bloom's taxonomy, using knowledge and application frequently. They knew and recognized techniques of classroom management, teaching strategies, and assessment when the elements were in front of them. However, pre-service candidates had never applied them in a classroom. That experience was to come in their clinical experience.

The methods faculty were encouraged that the pre-service candidates did know these pedagogical areas when they observed them. It meant that they were aware of these practices. After reading and analyzing their notes and reflections, it was apparent that the pre-service candidates could interpret what good teaching practice included. Figure 2 identifies the levels of Bloom's Taxonomy that the pre-service candidates used when taking notes and in their reflections about their observations during Rounds I and II. 


$\begin{array}{ll}\underline{\text { Rounds I }} & \frac{\text { Rounds II }}{\text { Knowledge }} \\ \text { Application } & \text { Synthesis }\end{array}$

Figure 2. Blooms Taxonomy pre-service candidates used in Rounds Observations.

Following the five-week experience, Rounds II produced data that were at a higher level of Bloom's Taxonomy. Their notes provided detailed analysis of what teachers did and why, as well as a synthesis of pedagogical techniques with their content. The notes were written by preservice candidates who had the experience of planning and conducting classes for five weeks. Clearly the pre-service candidates were now recognizing and synthesizing the work in the classrooms with the research-based practices of the teachers. These were identified in the statements that noted why strategies about pop quizzes could be used as formative assessment, and the effectiveness of using questioning to identify student misconceptions. Their vocabulary changed too, making use of more academic language and pedagogical terminology. They were concerned about implementing content standards, time management, scaffolding, and studentcentered classrooms with teachers as facilitators. Their skill at analysis and synthesis of classroom teaching with the pedagogical concepts taught in methods class was evident in the reflection papers.

The use of Rounds for pre-service candidates helped the university faculty determine where the pre-service candidates stood in their professional growth before an extended clinical experience and after that same experience. While the pre-service candidates believed that they were ready to teach in any classroom prior to the clinical experience, their reflections noted new understandings of the depth of pedagogical strategies needed in the classroom today.

The reflection papers from these pre-service candidates support Del Prete's (2006) model for linking practice experiences with theoretical learning about teaching. These case studies extend the work of Thompson and Crooner (2001), providing evidence that, when placed in a collaborative and supportive environment, pre-service candidates do experience the real world of teaching with students and classroom issues present. They learn to work with colleagues and to use academic language on the job. Pre-service candidates can debrief, asking the teacher being observed the "why" questions about selection of lesson content and responses to students. Immediate feedback during the debriefing meeting following Rounds classroom observation helped the pre-service candidates learn the why of planning and classroom management.

Future studies should be done on more extensive use of Rounds in a methods curriculum. For example, can a methods course cover all the aspects of teaching required by the learned societies with just Rounds visits? Do the Rounds visits have the same impact without a clinical experience? Studies in the future can test these elements for effectiveness.

What is the impact of Rounds on pre-service candidates' perception of teaching? In this study, Rounds used as defined clearly served as a means by which the pre-service candidates were able to share their thoughts with an experienced classroom teacher and observe how pedagogical practices could be used in a classroom. Rounds, in combination with the clinical experience, extended the pre-service candidates' awareness of research-based practices and the importance of these practices. Rounds served as a model for the pre-service candidates on the "how" of applying instruction, classroom management and assessment to authentic classrooms. Lastly, our grounded theory now defined Rounds as a means of demonstrating theory and 
practice at its best: the university and the school working together as a means to prepare preservice students for future classrooms.

\section{Limitations, Implications, and Future Research}

We selected an ethnographic approach to this research because we needed to learn what influence the Rounds visits had on pre-service candidates' perception of teaching. Were the preservice candidates gaining pedagogical content knowledge from the visits to observe practicing teachers prior to and after a ninety-hour field experience? Limitations arose in three areas: the number of participants both for pre-service candidates and practicing teachers, the self-reporting in the surveys, and the locations used.

The number of pre-service candidates was based on those who self-selected into the specific content areas of AYA English Language Arts and mathematics for their licenses. In the past, when our enrollment in the AYA program was high, these numbers would have been over 40 pre-service candidates. With the present enrollment, our numbers are much lower. However, we still need to learn the significance, if any, to the required pre-service candidates' program. All participants took part in the research; no pre-service candidate asked to opt out of the research.

Finding teachers who were willing to be participants in this research was more of a challenge than we anticipated. This research required a good amount of the teachers' time. Teachers had to write lesson plans in a format that the pre-service candidates would be able to follow during the flow of the class instruction. Teachers had to schedule pre-observation as well as post-observation meeting times. Only one mathematics teacher was open to asking her school principal for this time for meetings and was willing to write out her procedure. Fortunately, this mathematics teacher had nine years of experience that she shared with our students. Having more teachers to observe would have contributed to the pre-service candidates' observation of multiple teaching practices and classroom management techniques.

Finding principals willing to have groups of pre-service candidates enter their school buildings and premises was an issue we had not considered when making our requests for participation. The principals had to grant permission, allowing a flow of additional people into the building and space for the pre-observation and post-observation conferences. With the security issues that schools now face, we were delighted with the principals and teachers who allowed us to work in their buildings. This could be an issue in future research.

The researchers created the surveys to focus on what they wanted to learn from the preservice candidates. When completing the surveys, the time involved with responding to the questions and the limited number of questions could have led the pre-service candidates to focus their replies on one direction rather than relying on a free flow of information if they had not been given guiding questions.

The implications from this study suggest that structured observations of teachers help develop pre-service candidates' thinking regarding the usefulness of research-based pedagogical practices. As a result, the researchers are seeking more scheduled time during the fall semester for their candidates to observe and interact with teachers in a Rounds setting. Conducting methods classes within a school setting might allow for more frequent Rounds to occur.

This ethnographic research enabled these researchers to discover what pre-service candidates focused their attention on both at the start of intense field experiences and after those experiences. This information will help them and other university faculty tailor their methods classes to include more research-based pedagogical strategies for English Language Arts and 
mathematics methods classes. The results of this research should enrich any education courses taught during senior year to pre-service candidates.

\section{References}

Acheson, K. A., \& Gall, M. D. (1987), Techniques in the clinical supervision of teachers: Preservice and inservice applicatons. White Plains, NY: Longman, Inc.

Amidon, E. J., \& Hough, J. J. (1967). Interaction analysis: Theory, research, and application. Reading, MA: Addison-Wesley Pub. Co.

Blagg, D. (2009). Rounds for teachers. In Harvard Graduate School of Education. Retrieved from http://www.uknow.gse.harvard.edu/teaching/TC103 607.html.

Bogdan, R. C., \& Biklen, S. K. (1992). Qualitative research for education. Needham Heights, MA: Allyn and Bacon.

Bowen, G. A. (2006). Grounded theory and sensitizing concepts. International Journal of Qualitative Methods. 5(3), 1-9.

Bulmer, M. (1979). Concepts in the analysis of data. Sociological Review, 27, 651-677. doi: 10.1111/j.1467-954X.1979.tb00354.x

Del Prete, T. ( 2006). The "Rounds" model of professional development. From the Inside, Fall (1), $72-73$.

Denizen, N. K. (1989). Interpretive biography: Qualitative research methods series. (Vol. 17). Newbury Park, CA: Sage Publications, Inc. doi: 10.4135/9781412984584

Everston, C. M., \& Smithey, M. W. (2000). Mentoring effects on proteges' classroom practice: An experimental field study. The Journal of Educational Research, 9(5), 299-304.

Gibson, S., \& Dembo, M. H. (1984). Teacher efficacy: A construct validation-time to bring out positive student change. Journal of Educational Psychology, 76(4), 569-582. doi: 10.1037/00220663.76.4.569

Herrelko, J., \& Bowman, C. (2011). Building an adolescence to young adult capstone course. The Ohio Journal of Teacher Education, 24(2), 24-30.

Ladson-Billings, G. (2008). A letter to our next president. Journal of Teacher Education, 59(3), 235-239. doi: 10.1177/0022487108317466.

Lave, J., \& Wenger, E. (1991). Situated learning: Legitimate peripheral participation. Cambridge, MA: Cambridge University Press. 
Lortie, D. C. (1975). School teacher: A sociological study ( $2^{\text {nd }}$ ed.). Chicago, IL: The University of Chicago Press.

McNamara, D. R. (1981). Teaching skill: The question of questioning. The Journal of Educational Research, 23(2).

Patton, M. (1990). Qualitative evaluation and research methods (2nd ed.). Newbury Park, CA: Sage.

Rallis, S., Tedder, J., Lachman, A., \& Elmore, R. (2006). Superintendents in classrooms: From collegial conversations to collaborative action. Phi Delta Kappan, 87(7), 537-545. doi: $10.1177 / 003172170608700720$

Sarason, S. (1996). Revisiting “the culture of the school and the problem of change." New York: Teachers College Press.

Thompson, S., \& Crooner, D. D. (2001). Grand rounds: Not just for doctors. Action in Teacher Education, 23(3), 84-88. doi: 10.1080/01626620.2001.10463078

Torff, B., (1999). Tacit knowledge in teaching: Folk pedagogy and teacher education. (195213). In Tacit knowledge in professional practice: Researcher and practitioner perspective. Ed. R.J. Sternberg, J.A. Horvath. Mahwah, NJ: Earlbaum \& Assoc.

Virtue, D.C. (2005). A visit to ESOL Island: Notes on a shadowing experience with middle level English language learners in South Carolina. South Carolina Middle School Journal 13(1), 4244.

Wainwright, C. L., Flick, L. B., \& Morrell, P. D. (2003). Development of instruments for assessment of instructional practices in standards-based teaching. Journal of Mathematics and Science Collaborative Explorations, 6, 21-46.

Walsh, S. (2002). Construction or obstruction: Teacher talk and learner involvement in the EFL classroom. Language and Teaching Research, 6(1), 3-23. 